\title{
Relationship between Hypothyroidism and Non-Alcoholic Fatty Liver Disease: A Systematic Review and Meta-analysis
}

\author{
Weiwei $\mathrm{He}^{1}$, Xiaofei $\mathrm{An}^{2}$, Ling $\mathrm{Li}^{2}$, Xiaoqing Shao', Qian $\mathrm{Li}^{2}$, Qiuming $\mathrm{Yao}^{2}$ \\ and Jin-an Zhang ${ }^{3 *}$
}

\begin{abstract}
${ }^{1}$ Department of Endocrinology, Affiliated Hospital of Yanan University, Shanxi, China, ${ }^{2}$ Department of Endocrinology, Jinshan Hospital of Fudan University, Shanghai, China, ${ }^{3}$ Department of Endocrinology, Shanghai University of Medicine \& Health Sciences Affiliated Zhoupu Hospital, Shanghai, China
\end{abstract}

\section{OPEN ACCESS}

Edited by: Alessandro Antonelli, University of Pisa, Italy

Reviewed by: Maria Moreno,

University of Sannio, Italy Sabrina Rosaria Paparo, University of Pisa, Italy

${ }^{*}$ Correspondence: Jin-an Zhang zhangjinan@hotmail.com

Specialty section: This article was submitted to Thyroid Endocrinology,

a section of the journal Frontiers in Endocrinology

Received: 06 July 2017 Accepted: 14 November 2017 Published: 29 November 2017

Citation:

He W, An X, Li L, Shao X, Li Q, Yao Q and Zhang J-a (2017) Relationship between Hypothyroidism and Non-Alcoholic Fatty Liver Disease: A Systematic Review and Meta-analysis.

Front. Endocrinol. 8:335. doi: 10.3389/fendo.2017.00335
Background: Previous studies propose that hypothyroidism might play a crucial role in the pathogenesis of non-alcoholic fatty liver disease (NAFLD), but findings from published studies on the relationship between hypothyroidism and NAFLD are still controversial. Our study aimed to make a comprehensive evaluation of the relationship between hypothyroidism and NAFLD through a meta-analysis.

Methods: PubMed, China Dissertation Database, and EMBASE databases were searched to find observational studies assessing the relationship between hypothyroidism and NAFLD. The pooled odds ratios (ORs) with 95\% confidence intervals (95\% Cls) were calculated to evaluate the strength of the relationship between hypothyroidism and NAFLD through meta-analysis.

Results: Thirteen articles were ultimately included in our meta-analysis. Meta-analysis of the 13 studies found a high correlation between hypothyroidism and NAFLD (OR $=1.52$, $95 \% \mathrm{Cl} 1.24-1.87, P<0.001)$. Meta-analysis of 9 studies providing adjusted ORs found that hypothyroidism was independently correlated with NAFLD $(O R=1.72,95 \% \mathrm{Cl}$ 1.32-2.23, $P<0.001$ ). Subgroup analysis found that both overt hypothyroidism and subclinical hypothyroidism were significantly correlated with NAFLD, and the pooled ORs were 1.70 (95\% Cl 1.23-2.36, $P=0.002)$ and 1.40 (95\% Cl 1.10-1.77, $P=0.006)$, respectively. Besides, meta-analysis of studies providing adjusted ORs also found that both overt hypothyroidism and subclinical hypothyroidism were independently correlated with NAFLD, and the pooled ORs were $1.81(95 \% \mathrm{Cl} 1.30-2.52, P<0.001)$ and 1.63 (95\% Cl 1.19-2.24, $P=0.002)$, respectively.

Conclusion: The meta-analysis provides strong epidemiological evidence for the relationship between hypothyroidism and NAFLD. Both individuals with subclinical and overt hypothyroidism are at higher risk for NAFLD than euthyroid subjects.

Keywords: hypothyroidism, subclinical hypothyroidism, non-alcoholic fatty liver disease, meta-analysis, relationship

\section{INTRODUCTION}

The prevalence of non-alcoholic fatty liver disease (NAFLD) has increased substantially during the past decades, and it has become the leading cause of liver disease worldwide, which may be partly attributed to the rising prevalence of obesity (1). NAFLD is a chronic liver disease defined as hepatic accumulation of fat in the absence of excess alcohol consumption and not only insulin resistance 
(IR) but also genetic predisposition play a key role in its pathogenesis (1). NAFLD can be divided into two main histological categories, namely nonalcoholic fatty liver and nonalcoholic steatohepatitis, which is the progressive subtype of NAFLD and can further induce liver cirrhosis and hepatocellular carcinoma (2). An increasing number of diseases have been reported to be linked to NAFLD, such as cardiovascular disease, type 2 diabetes, chronic kidney disease, and cancer (3-5). The prevention and treatment of NAFLD have become the focus of medical research in recent years, and identifying the risk factors for NAFLD is critical to develop effective preventive interventions against NAFLD.

Hypothyroidism is a common disease of the endocrine system that affects lifelong health. The physiological role of the thyroid gland has been taken seriously by many scholars, not just because of the critical role of thyroid hormones in cell metabolism and energy homeostasis (6) but also for the more important fact that thyroid dysfunction is associated with numerous diseases (7). Hypothyroidism comprises subclinical hypothyroidism and overt hypothyroidism. Subclinical hypothyroidism is considered as a disease with an elevated thyroid-stimulating hormone (TSH) level than normal range, normal serum free thyroxine (fT4) level and absence of obvious clinical manifestation. Overt hypothyroidism is defined as a disease with an elevated TSH level and a lower fT4 level, and it may be accompanied by obvious clinical symptoms. Some studies have found that both overt hypothyroidism and subclinical hypothyroidism are associated with cardiovascular diseases and mortality. Other studies also have found that either overt hypothyroidism or subclinical hypothyroidism may be associated with other diseases, such as chronic kidney disease, dementia, and fractures (8-10).

Previous studies propose that hypothyroidism might play a crucial role in the pathogenesis of NAFLD. Some studies report that the prevalence of hypothyroidism is from 15.2 to $36.3 \%$ among patients with NAFLD, indicating that hypothyroidism is a common concomitant disease of NAFLD and may be related to the development of NAFLD (11). At present, there are a number of observational studies which have explored the relationship between hypothyroidism and NAFLD. Some studies suggested a strong correlation between hypothyroidism and $\operatorname{NAFLD}(12,13)$, but there were also studies pointing out that there was no correlation $(14,15)$. Therefore, the association between hypothyroidism and NAFLD risk remains in dispute up to now. Thus, it is necessary to make certain about the relation between hypothyroidism and NAFLD risk through a meta-analysis.

\section{MATERIALS AND METHODS}

\section{Search Strategy}

We followed the PRISMA method for conducting a meta-analysis of observational studies (16). In order to select the appropriate studies to be included in our meta-analysis, we searched for published studies in PubMed, China Dissertation Database, and EMBASE databases using the following keywords and terms: (hypothyroidism or thyroid dysfunction or thyroid stimulating hormone or TSH) and (nonalcoholic fatty liver disease or nonalcoholic fatty liver disease or NAFLD or fatty liver). All studies we had searched were published before May 2017, and there was no imposed restriction on country or ethnicity.

\section{Inclusion and Exclusion Criteria}

Our inclusion criteria were as follows: (1) cohort, cross-sectional, or case-control studies which investigated the association between hypothyroidism and NAFLD; (2) all studies must report odds ratios (ORs) with 95\% confidence intervals (95\% CIs) values or other values which could be converted into ORs; (3) included NAFLD patients must be diagnosed with an ultrasound examination or pathologic examination to make a clear definite diagnosis, and other diseases that could cause hepatic steatosis were excluded; and (4) the diagnosis of hypothyroidism must be based on biochemical tests including TSH levels and T4/FT4 levels.

\section{Data Collection and Quality Assessment}

The final data were abstracted from each study using standardized form: the first author's name, year of publication, study design, study location, number of participants, participant baseline characteristics (age and gender), method used to identify and verify NAFLD as well as thyroid function, definition of hypothyroidism including overt hypothyroidism or subclinical hypothyroidism. We used Newcastle Ottawa Scale to evaluate the quality of included studies (17). The selection of studied individuals, the comparability between exposed and non-exposed individuals, and the assessment of outcomes were evaluated (17). Studies scoring 7-9 points were considered to have high quality.

\section{Statistical Analysis}

We used ORs with 95\% CIs to test the relationship between hypothyroidism and NAFLD. Study-specific ORs were pooled using meta-analysis. The heterogeneity was evaluated by $I^{2}$ statistic and Cochran's Q-test, and $I^{2}$ more than $50 \%$ or $P$ of $Q$-test less than 0.10 showed significant heterogeneity $(18,19)$. DerSimonian-Laird

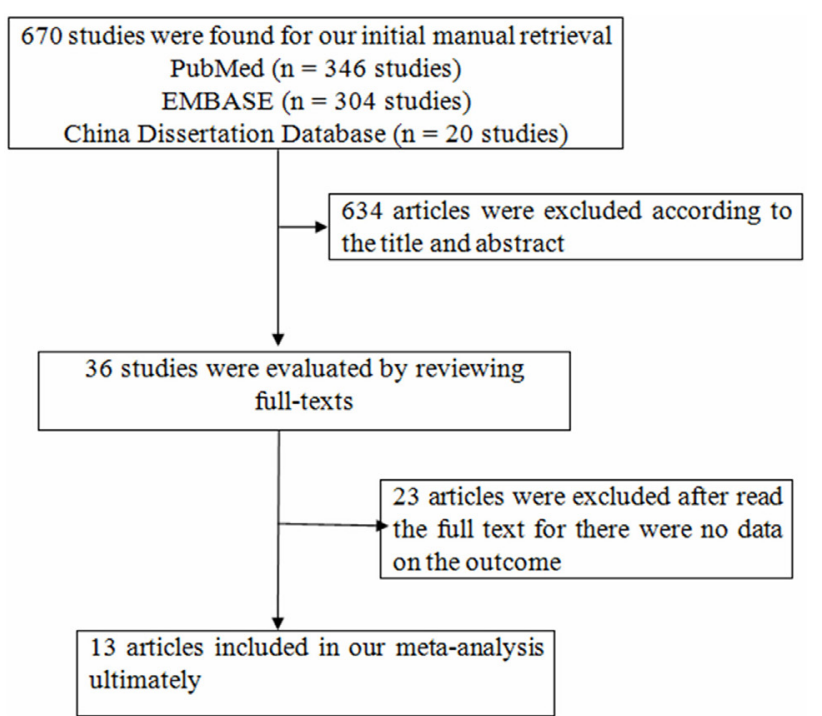

FIGURE 1 | Flowchart of study selection in the meta-analysis. 
TABLE 1 | Characteristics of studies on the association between hypothyroidism and NAFLD.

\begin{tabular}{|c|c|c|c|c|c|c|c|}
\hline Reference & Country & $\begin{array}{l}\text { Study } \\
\text { design }\end{array}$ & $\begin{array}{l}\text { Study sample } \\
\text { (mean age; female, \%) }\end{array}$ & $\begin{array}{l}\text { Diagnosis } \\
\text { of NAFLD }\end{array}$ & Definition of hypothyroidism & Adjusted factors & Quality \\
\hline Bano et al. (52) & Netherlands & Cohort & $\begin{array}{l}9,419 \text { individuals } \\
\text { (64.7 years; } 56.5 \%)\end{array}$ & Ultrasound & $\begin{array}{l}\text { Subclinical hypothyroidism was } \\
\text { defined as serum } \mathrm{TSH}>4.0 \mathrm{mIU} / \mathrm{L} \\
\text { and } \mathrm{FT} 4 \text { levels within the reference } \\
\text { range. Overt hypothyroidism was } \\
\text { defined as serum } \mathrm{TSH}>4.0 \mathrm{mIU} / \mathrm{L} \\
\text { and } \mathrm{FT} 4 \text { levels }<0.85 \mathrm{ng} / \mathrm{dl}\end{array}$ & $\begin{array}{l}\text { Age, sex, cohort, follow-up } \\
\text { time, use of hypolipidemic } \\
\text { drugs and cardiovascular }\end{array}$ & 9 \\
\hline Chung et al. (12) & Korea & $\begin{array}{l}\text { Cross- } \\
\text { sectional }\end{array}$ & $\begin{array}{l}4,648 \text { individuals } \\
(48.6 \pm 11.8 ; 62.4 \%)\end{array}$ & Ultrasound & $\begin{array}{l}\text { Subclinical hypothyroidism } \\
\text { (TSH > } 4.1 \mathrm{mlU} / \mathrm{L} ; \text { normal free T4 } \\
\text { concentration); Overt hypothyroidism: } \\
\text { fT4 level < } 0.7 \mathrm{ng} / \mathrm{dL}\end{array}$ & $\begin{array}{l}\text { Some known risk factors of } \\
\text { NAFLD }\end{array}$ & 8 \\
\hline Lee et al. (44) & Korea & Cohort & $\begin{array}{l}18,544 \text { individuals } \\
(37.8 \pm 5.7 ; 50 \%)\end{array}$ & Ultrasound & $\begin{array}{l}\text { Subclinical hypothyroidism } \\
\text { (TSH > } 4.2 \mathrm{mlU} / \mathrm{L} \text {, normal fT4); overt } \\
\text { hypothyroidism (TSH > } 4.2 \mathrm{mlU} / \mathrm{L} \text {, } \\
\text { fT4 }<10.97 \mathrm{ng} / \mathrm{dL})\end{array}$ & $\begin{array}{l}\text { Sex, age, BMl, TGs, } \\
\text { and HDL }\end{array}$ & 9 \\
\hline Pacifico et al. (45) & Italy & $\begin{array}{l}\text { Cross- } \\
\text { sectional }\end{array}$ & $\begin{array}{l}402 \text { individuals } \\
\text { (6-16 years) }\end{array}$ & Ultrasound & $\begin{array}{l}\text { Subclinical hypothyroidism } \\
\text { (TSH > } 4.1 \text { mlU/L with normal FT4); } \\
\text { overt hypothyroidism (TSH > } 4.1 \text { mlU/ } \\
\text { L with FT4 }<0.7 \text { ng/dL) }\end{array}$ & $\begin{array}{l}\text { Age, gender, pubertal status, } \\
\text { and BMI-SDS (or WC) as well } \\
\text { as FT3 and FT4 }\end{array}$ & 7 \\
\hline $\begin{array}{l}\text { Kaltenbach } \\
\text { et al. (46) }\end{array}$ & Germany & $\begin{array}{l}\text { Cross- } \\
\text { sectional }\end{array}$ & $\begin{array}{l}332 \text { individuals } \\
\text { including } 99 \text { NAFLD } \\
\text { patients (14.1 } \pm 1.9 \text {; } \\
33.3 \%) \text { and } 233 \\
\text { non-NAFLD subjects } \\
(13.9 \pm 1.8 ; 58.8 \%)\end{array}$ & Ultrasound & $\begin{array}{l}\text { Subclinical hypothyroidism } \\
\text { (TSH }>4 \mu \cup / m L \text {, normal thyroxine) }\end{array}$ & $\begin{array}{l}\text { Age, BMI-SDS, and stage of } \\
\text { puberty }\end{array}$ & 7 \\
\hline $\begin{array}{l}\text { Liangpunsakul } \\
\text { and Chalasani (47) }\end{array}$ & US & $\begin{array}{l}\text { Case- } \\
\text { control }\end{array}$ & $\begin{array}{l}616 \text { individuals }(49 \pm 13 \\
59 \%)\end{array}$ & $\begin{array}{l}\text { Enzymatic } \\
\text { procedures }\end{array}$ & Overt hypothyroidism & $\begin{array}{l}\text { Diabetes mellitus, } \\
\text { hyperlipidemia, and } \\
\text { hypertension }\end{array}$ & 7 \\
\hline $\begin{array}{l}\text { Pagadala } \\
\text { et al. (13) }\end{array}$ & US & $\begin{array}{l}\text { Case- } \\
\text { control }\end{array}$ & $\begin{array}{l}663 \text { individuals (50.4; } \\
56.2 \%)\end{array}$ & Histological & Overt hypothyroidism & $\begin{array}{l}\text { Gender, ethnicity, diabetes, } \\
\text { HTN, hyperlipidemia, and } \\
\text { hypothyoidism and mean } \\
\text { (SD) }\end{array}$ & 7 \\
\hline Parikh et al. (48) & $\begin{array}{l}\text { Western } \\
\text { India }\end{array}$ & $\begin{array}{l}\text { Case- } \\
\text { control }\end{array}$ & $\begin{array}{l}800 \text { individuals including } \\
500 \text { NAFLD patients } \\
(44.3 \pm 3.2 ; 64.6 \%) \\
\text { and } 300 \text { controls } \\
(41.6 \pm 3.89 ; 66 \%)\end{array}$ & Ultrasound & $\begin{array}{l}\text { Subclinical hypothyroidism } \\
\text { (TSH > } 5.5 \mathrm{IU} / \mathrm{mL} \text { but }<10 \mathrm{IU} / \mathrm{mL} \text { ) } \\
\text { and overt hypothyroidism } \\
\text { (TSH > } 10 \mathrm{IU} / \mathrm{mL} \text { ) }\end{array}$ & $\begin{array}{l}\text { Age, gender, alcohol use, and } \\
\text { serum triglycerides }\end{array}$ & 7 \\
\hline Xu et al. (49) & China & $\begin{array}{l}\text { Case- } \\
\text { control }\end{array}$ & $\begin{array}{l}654 \text { individuals including } \\
327 \text { subclinical } \\
\text { hypothyroidism patients } \\
\text { and } 327 \text { controls }\end{array}$ & Ultrasound & $\begin{array}{l}\text { Subclinical hypothyroidism } \\
\text { (TSH }>4.5 \mathrm{mlU} / \mathrm{L} \text {; normal thyroxine } \\
\text { level) }\end{array}$ & $\begin{array}{l}\text { Waist circumference, systolic } \\
\text { blood pressure, diastolic } \\
\text { blood pressure, triglyceride, } \\
\text { HDL cholesterol, and fasting } \\
\text { plasma glucose }\end{array}$ & 7 \\
\hline $\begin{array}{l}\text { Posadas-Romero } \\
\text { et al. (50) }\end{array}$ & Mexico & $\begin{array}{l}\text { Cross- } \\
\text { sectional }\end{array}$ & $\begin{array}{l}753 \text { individuals including } \\
133 \text { NAFLD cases and } \\
620 \text { controls ( } 51.9 \\
63.9 \%)\end{array}$ & $\begin{array}{l}\text { Enzymatic } \\
\text { procedures }\end{array}$ & $\begin{array}{l}\text { Subclinical hypothyroidism } \\
\text { (TSH > } 4.5 \mathrm{mlU} / \mathrm{L} \text {; normal thyroxine } \\
\text { level) }\end{array}$ & None & 6 \\
\hline $\begin{array}{l}\text { Ittermann } \\
\text { et al. (51) }\end{array}$ & Germany & $\begin{array}{l}\text { Cross- } \\
\text { sectional }\end{array}$ & 3,661 individuals & Ultrasound & $\begin{array}{l}\text { Hypothyroidism was defined by } \\
\text { increased serum TSH concentrations } \\
\text { and decreased FT3 or FT4 } \\
\text { concentrations }\end{array}$ & None & 6 \\
\hline $\begin{array}{l}\text { Eshraghian } \\
\text { et al. (14) }\end{array}$ & Iran & $\begin{array}{l}\text { Cross- } \\
\text { sectional }\end{array}$ & $\begin{array}{l}832 \text { individuals including } \\
127 \text { NAFLD patients } \\
(48.2 \pm 12.8) \text { and } 705 \\
\text { controls }(36.9 \pm 18.7) \\
(61.3 \%)\end{array}$ & Ultrasound & $\begin{array}{l}\text { Subclinical hypothyroidism } \\
\text { (TSH > } 5.2 \mathrm{mlU} / \mathrm{L} \text {, normal fT4); overt } \\
\text { hypothyroidism (TSH > } 5.2 \mathrm{mlU} / \mathrm{L} \text {, } \\
\text { fT4 }<11.5 \mathrm{ng} / \mathrm{dL} \text { ) }\end{array}$ & None & 6 \\
\hline $\begin{array}{l}\text { Wang and } \\
\text { Zhao (53) }\end{array}$ & China & $\begin{array}{l}\text { Cross- } \\
\text { sectional }\end{array}$ & $\begin{array}{l}806 \text { individuals } \\
(56.99 \pm 7.98 ; 81.3 \%)\end{array}$ & Ultrasound & $\begin{array}{l}\text { Subclinical hypothyroidism } \\
\text { (TSH > } 4.2 \mu U \mathrm{~mL}, \text { FT4: 12-22) }\end{array}$ & None & 6 \\
\hline
\end{tabular}


random-effect meta-analysis was adopted when obvious heterogeneity existed (20). Mantel-Haenszel fixed meta-analysis was adopted when no obvious heterogeneity existed (21). For the existence of obvious heterogeneity, subgroup analyses and metaregression analyses were performed to explore possible sources of heterogeneity. We conducted subgroup analyses for overt hypothyroidism and subclinical hypothyroidism, respectively. In the meta-regression analyses, study design, country, number of participants, adjusted estimates and types of hypothyroidism were used as covariates. Sensitivity analysis was implemented by excluding those studies with low scores of quality. Publication bias was evaluated by funnel plot and Egger's test (22). STATA 12.0 (StataCorp, College Station, TX, USA) was utilized in data analysis, and $P<0.05$ was considered statistically significant.

\section{RESULTS}

\section{Study Selection}

We searched the databases from mentioned above and found 670 articles, while 634 articles were excluded according to the title and abstract for the following reasons: animal studies, the main purpose of these studies unrelated to the content of the present study (Figure 1). Thirty-six studies were evaluated by reviewing full-texts. Twenty-three articles were excluded after reading full-texts, for there were no data on the outcomes of interest (11, 15, 23-43). There were 13 articles included in our meta-analysis ultimately (12-14, 44-53). Following the aforementioned search, a total of 13 studies with 42,143 participants were incorporated into our final analysis studies.

\section{Study Characteristics}

Table 1 shows the characteristics of 13 studies on the association between hypothyroidism and NAFLD (Table 1). Nine studies reported outcomes on the association between subclinical hypothyroidism and NAFLD, and six studies reported outcomes on the association between overt hypothyroidism and NAFLD (Table 1). Those 13 studies were published from 2003 to 2017, and the number of recruited participants was from 332 to 18,544 . Nine studies provided adjusted ORs and four studies only provided native ORs. The quality of the included studies was shown in Table 1, and nine studies had high quality (Table 1).

\section{Meta-Analysis}

Meta-analysis of the 13 studies found a high correlation between hypothyroidism (including both overt hypothyroidism and subclinical hypothyroidism) and NAFLD (OR $=1.52,95 \% \mathrm{CI}$ 1.24-1.87, $P<0.001$ ) (Figure 2A, Table 2). After excluding 4 studies without adjusted ORs, meta-analysis of 9 left studies found that hypothyroidism was significantly and independently correlated with NAFLD $(\mathrm{OR}=1.72,95 \%$ CI 1.32-2.23, $P<0.001)$ (Figure 2B).

Obvious heterogeneity was found among these 13 studies $\left(I^{2}=75.1 \% ; P<0.001\right.$, Table 2$)$. In the meta-regression analyses, we found that study design was a possible source of heterogeneity $(P=0.16)$, but other covariates were not.

Meta-analysis of six studies found that overt hypothyroidism was significantly correlated with NAFLD (OR $=1.70,95 \%$
CI 1.23-2.36, $P<0.002$ ) (Figure 3A, Table 2). After excluding one study without adjusted ORs, meta-analysis of the other five studies found that overt hypothyroidism was significantly and independently correlated with NAFLD $(\mathrm{OR}=1.81,95 \% \mathrm{CI}$ $1.30-2.52, P<0.001$ ) (Figure 3B). No obvious heterogeneity was found among those five studies $\left(I^{2}=36.3 \% ; P=0.179\right)$.

Meta-analysis of nine studies found that subclinical hypothyroidism was significantly correlated with NAFLD (OR $=1.40$, 95\% CI 1.10-1.77, $P<0.006$ ) (Figure 4A). After excluding three studies without providing adjusted ORs, meta-analysis of six left studies found that overt hypothyroidism was significantly correlated with NAFLD $(\mathrm{OR}=1.63,95 \%$ CI 1.19-2.24, $P<0.002)$ (Figure 4B).

Funnel plots did not show obvious indications of publication bias (Figures 5A,B). The $P$ values of Egger's test in the metaanalyses relating overt hypothyroidism and subclinical hypothyroidism were 0.35 and 0.17 , respectively.

\section{DISCUSSION}

Although previous studies propose that hypothyroidism might play a crucial role in the pathogenesis of NAFLD, some observational studies fail to find an obvious association between hypothyroidism and NAFLD. However, based on the results of the present meta-analysis, hypothyroidism plays an important role in the pathogenesis of NAFLD. The meta-analysis suggests epidemiological evidence for the obvious relationship between hypothyroidism and NAFLD, and the impact of hypothyroidism is independent from other known risk factors for NAFLD. Besides, both subclinical hypothyroidism and overt hypothyroidism are independently related to NAFLD. It is more remarkable that our study, which comprised 13 available studies from 11 countries, is the first meta-analysis integrating the evidence for the relationship between hypothyroidism and NAFLD.

According to our study, hypothyroidism independently increases the risk of NAFLD, which has some implications in the screening of hypothyroidism and NAFLD. It may be helpful for the screening of NAFLD among hypothyroidism patients since those patients are at higher risk of developing NAFLD. Meanwhile, it

TABLE 2 | Summary of the main findings in the meta-analysis of the association between hypothyroidism and NAFLD.

\begin{tabular}{|c|c|c|c|c|c|}
\hline \multirow[t]{2}{*}{ Outcomes } & \multirow{2}{*}{$\begin{array}{c}\text { Studies } \\
\text { (participants) }\end{array}$} & \multicolumn{2}{|c|}{ Pooled estimates } & \multicolumn{2}{|c|}{ Heterogeneity } \\
\hline & & OR $(95 \% \mathrm{Cl})$ & $P$-value & $I^{2}$ & $P$ \\
\hline \multicolumn{6}{|c|}{ Hypothyroidism } \\
\hline Total studies & $13(42,143)$ & $1.52(1.24-1.87)$ & $<0.001$ & $75.1 \%$ & $<0.001$ \\
\hline $\begin{array}{l}\text { Studies with } \\
\text { adjustment }\end{array}$ & $9(36,078)$ & $1.72(1.32-2.23)$ & $<0.001$ & $80.0 \%$ & $<0.001$ \\
\hline \multicolumn{6}{|c|}{ Overt hypothyroidism } \\
\hline Total studies & $6(34,735)$ & $1.70(1.23-2.36)$ & $<0.002$ & $37.9 \%$ & 0.153 \\
\hline $\begin{array}{l}\text { Studies with } \\
\text { adjustment }\end{array}$ & $5(33,903)$ & $1.81(1.30-2.52)$ & $<0.001$ & $36.3 \%$ & 0.179 \\
\hline \multicolumn{6}{|c|}{ Subclinical hypothyroidism } \\
\hline Total studies & $9(36,390)$ & $1.40(1.10-1.77)$ & $<0.006$ & $73 \%$ & $<0.001$ \\
\hline $\begin{array}{l}\text { Studies with } \\
\text { adjustment }\end{array}$ & $6(33,999)$ & $1.63(1.19-2.24)$ & $<0.002$ & $80.6 \%$ & $<0.001$ \\
\hline
\end{tabular}




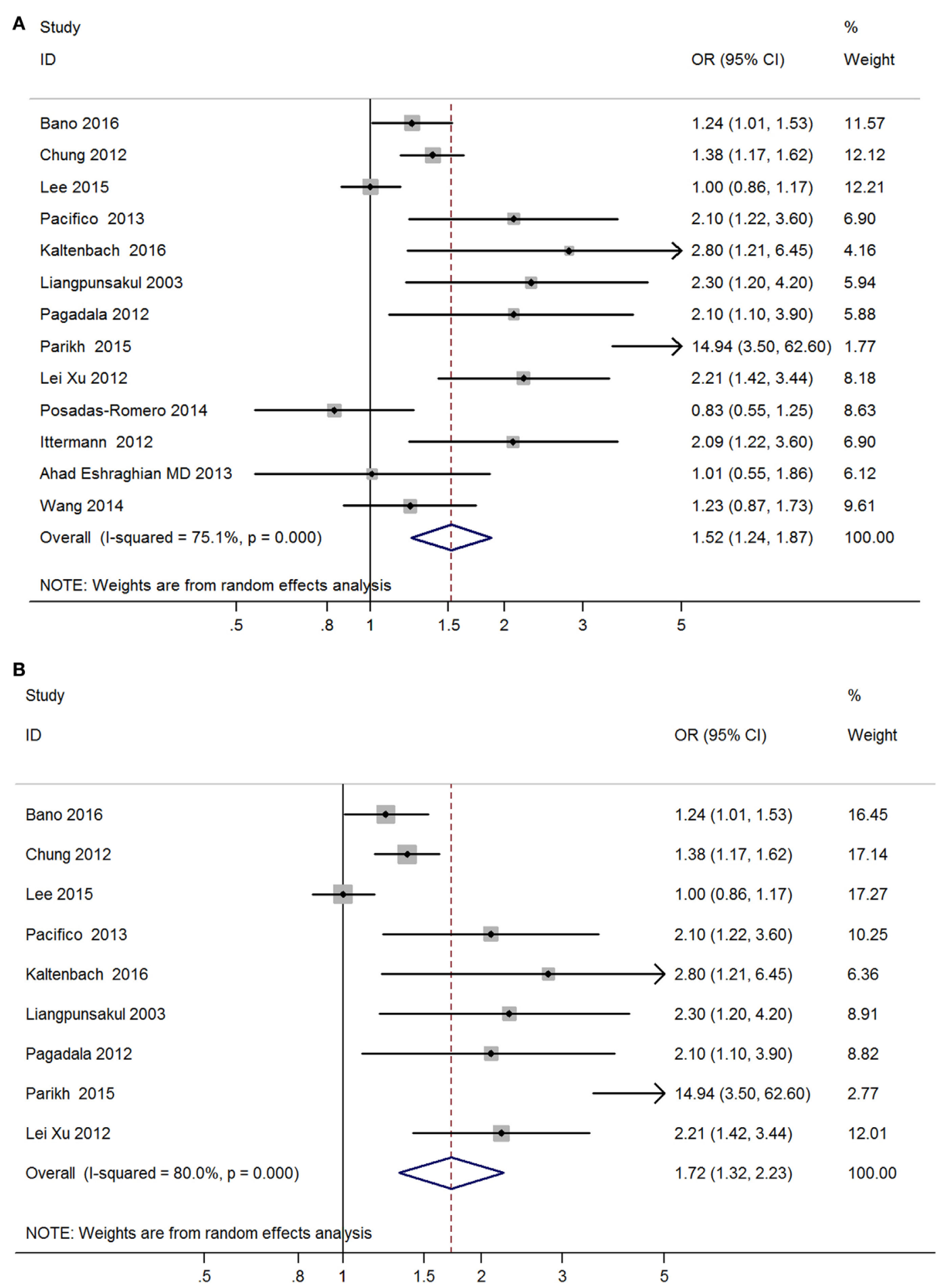

FIGURE 2 | Forest plots in the meta-analysis of the relationship between hypothyroidism and non-alcoholic fatty liver disease (NAFLD). (A) Forest plot suggested that hypothyroidism was correlated with NAFLD. (B) Forest plot suggested that hypothyroidism was independently correlated with NAFLD.

may also be helpful to identify hypothyroidism in patients with NAFLD and to give an appropriate treatment for hypothyroidism. Therefore, the results of this study is of great significance in the preventive medicine of hypothyroidism and NAFLD.
Our results demonstrate that either overt hypothyroidism or subclinical hypothyroidism independently increases the risk of NAFLD. Some studies have laid the foundation for the findings of the meta-analysis by providing some possible explanations 


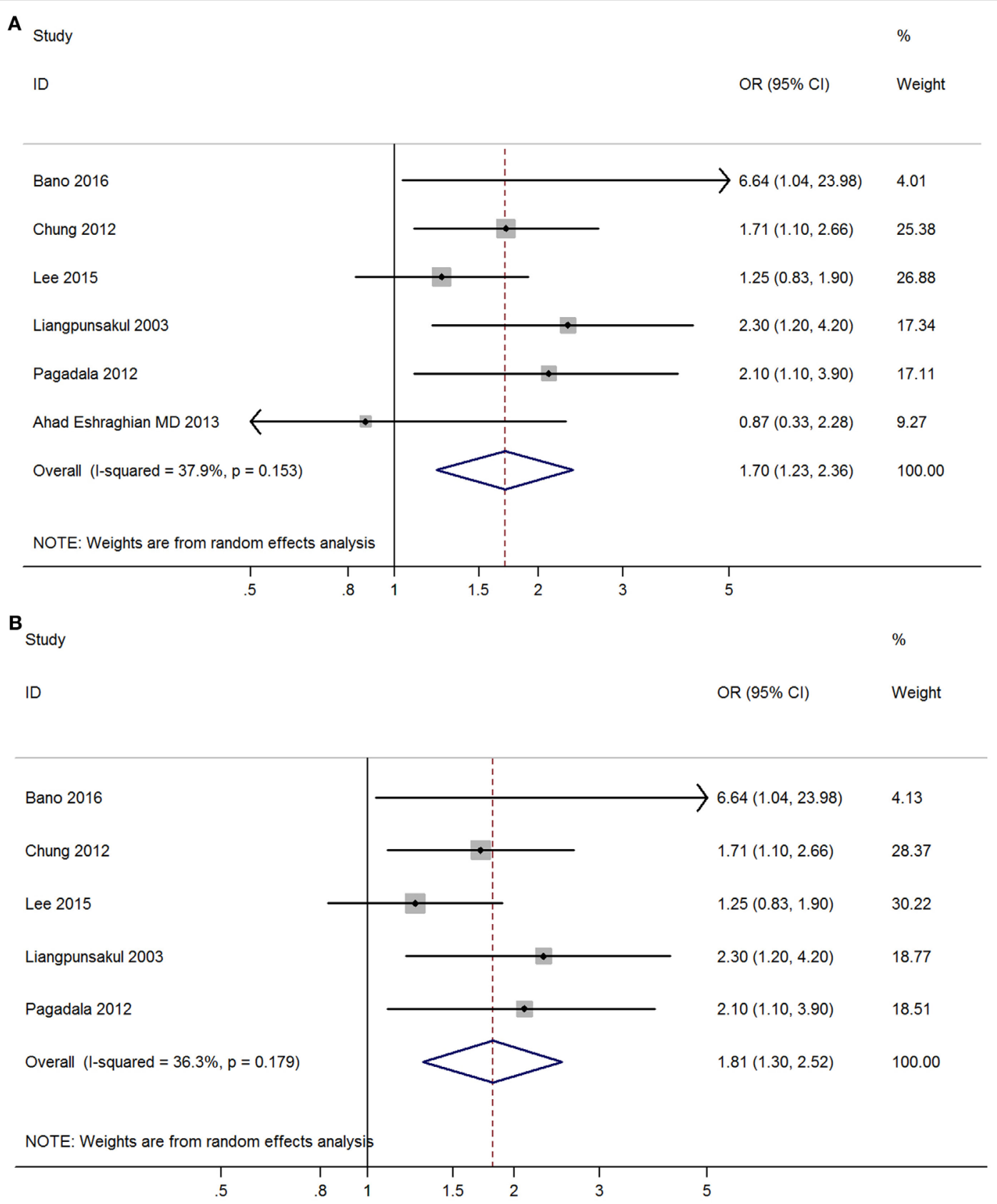

FIGURE 3 | Forest plots in the meta-analysis of the relationship between overt hypothyroidism and non-alcoholic fatty liver disease (NAFLD). (A) Forest plot suggested that overt hypothyroidism was correlated with NAFLD. (B) Forest plot suggested that overt hypothyroidism was independently correlated with NAFLD.

for the molecular mechanism underlying the relationship between hypothyroidism and NAFLD. There are several possible mechanisms which can explain the relationship between hypothyroidism and NAFLD. First, obvious relations between hypothyroidism and metabolic changes have been reported, which include IR, dyslipidemia and obesity and they have important roles in the development of NAFLD $(54,55)$. Both IR and obesity are vital factors in the development of NAFLD, which are also common in hypothyroidism patients compared to those general population (56). IR can accelerate liver injury in NAFLD (57). Besides, Demir et al. found that hypothyroidism can cause NAFLD in rat models, and pointed out that obesity is one of the key factors in the relationship between hypothyroidism and NAFLD (29). The metabolic changes aforesaid among hypothyroidism patients can thus further result in the development of NAFLD $(54,55)$. Second, thyroid hormones can regulate lipid metabolism in the liver via thyroid hormone receptor $\beta$, and they can decrease cholesterol and triglyceride levels (58-60). It is worth mentioning that lower levels of thyroid hormones in hypothyroidism can increase the levels of 


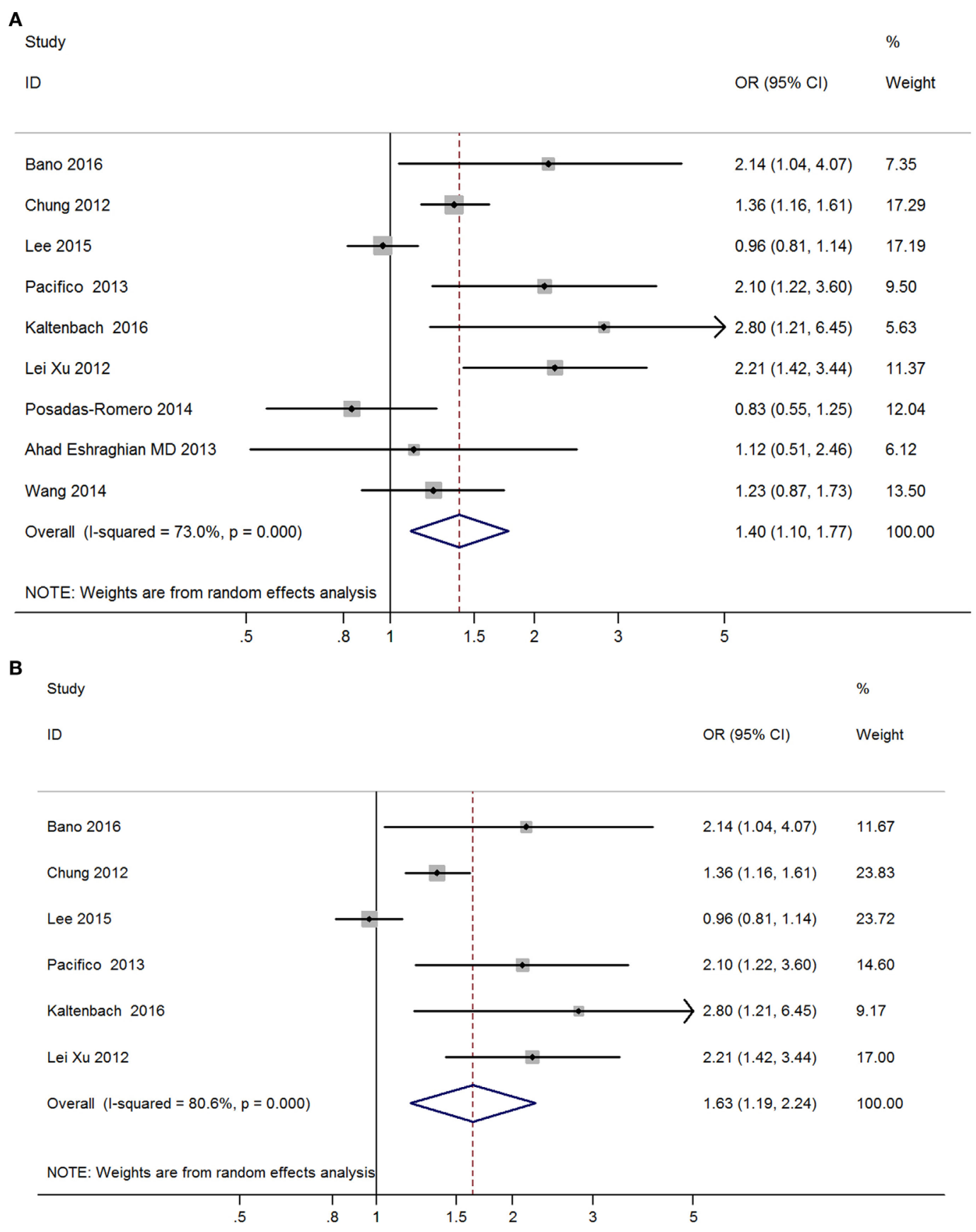

FIGURE 4 | Forest plots in the meta-analysis of the relationship between subclinical hypothyroidism and non-alcoholic fatty liver disease (NAFLD). (A) Forest plot suggested that subclinical hypothyroidism was correlated with NAFLD. (B) Forest plot suggested that subclinical hypothyroidism was independently correlated with NAFLD.

cholesterol, low-density lipoproteins and triglyceride due to the delivery of hepatic fatty acids, but decrease the level of highdensity lipoprotein (HDL), and thus can affect lipid metabolism (61). Therefore, patients with overt hypothyroidism often have fatty infiltration of the liver and thus have a higher risk for NAFLD (47). Hypercholesterolemia caused by hypothyroidism also plays an important role in the pathogenesis of NAFLD
$(41,47)$. Thirdly, TSH itself can have a direct impact on the function of hepatocytes via TSH receptor signal (62-64). TSH can directly increase hepatic gluconeogenesis, repress hepatic bile acid synthesis, and cause hypercholesterolemia by decreasing HMG-CoA reductase phosphorylation (63-65), which further leads to the development of NAFLD. Finally, elevated oxidative stress markers can be observed in hypothyroidism patients 


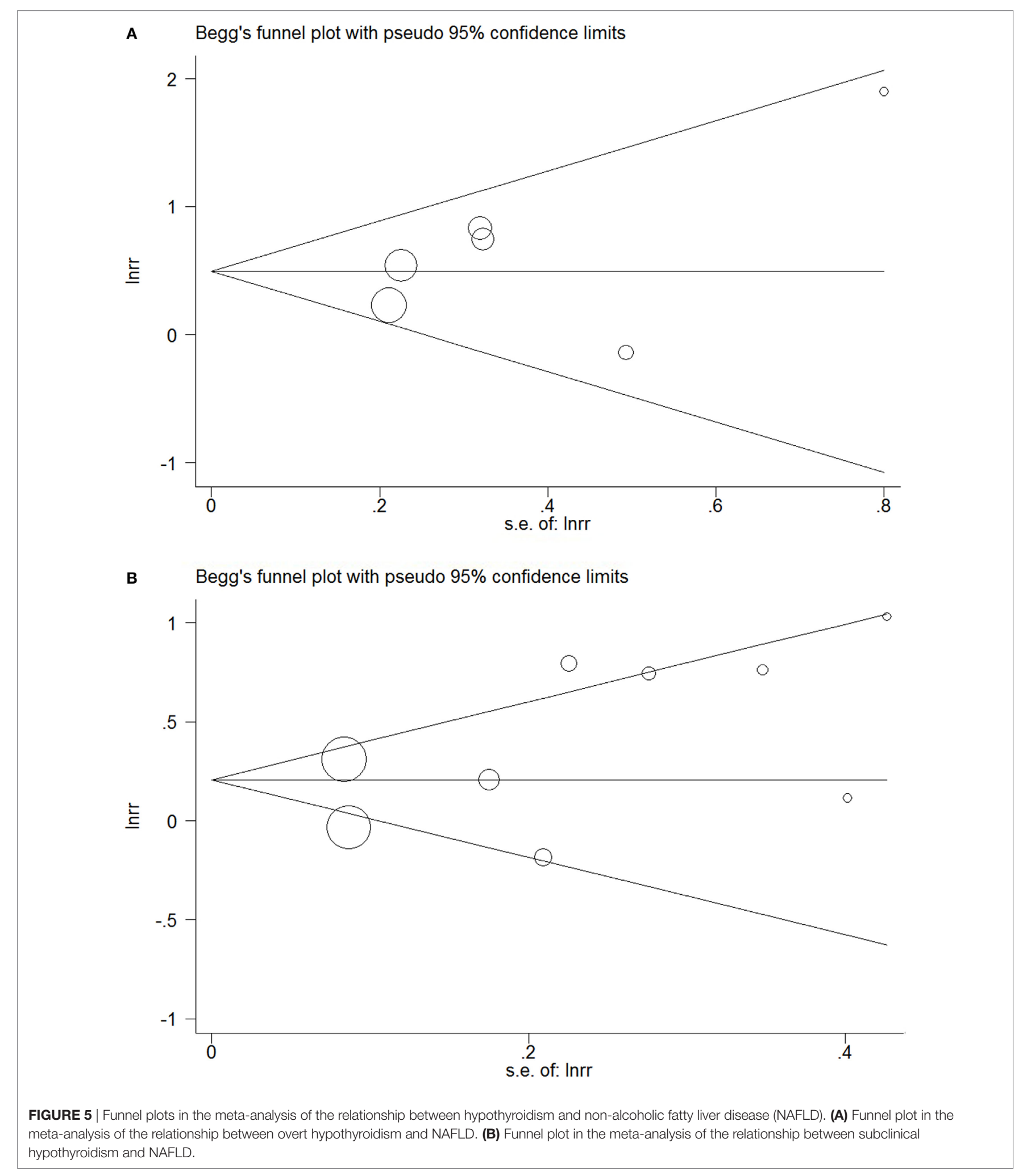

(66). Oxidative stress is one of the mechanisms of NAFLD, and oxidative stress in liver tissue among hypothyroidism patients can cause cellular injury and IR via reducing beta-oxidation of fatty acids and increasing peroxidation of lipids (66).
Previous studies have found that thyroid hormones have important roles in regulating lipid metabolism in the liver via thyroid hormone receptors (58-60). Apart from thyroid hormones, thyroid hormone derivatives also have been reported 
to exert important effects on the lipid metabolism in the liver (67-69). 3,5-Diiodo-L-thyronine (T2) is the main type of thyroid hormone derivatives, and some studies has demonstrated that $\mathrm{T} 2 \mathrm{has}$ an lipid-lowering effect and can reduce the excess fat in cultured hepatocytes $(68,69)$. In vivo studies also have found that T2 has some important effects on the lipid metabolism of liver, such as reducing lipid accumulation and stimulating the pathways of lipid oxidation $(70,71)$. The above findings suggest that some thyroid hormone derivatives has protective effects against NAFLD, which can be promising treatments for NAFLD $(67,71)$.

According to the results of the present research, we found an obvious phenomenon that the correlation between overt hypothyroidism and NAFLD was more significant than that between subclinical hypothyroidism and NAFLD. As mentioned above, overt hypothyroidism is defined as having a much higher TSH level and lower T4 and T3 levels compared to subclinical hypothyroidism. The more significant correlation between overt hypothyroidism and NAFLD may be explained by the synergistic effects of higher TSH level and lower thyroid hormones in the pathogenesis of NAFLD, because TSH itself may induce hepatocyte steatosis via TSH receptor signal (72).

Although we carried out this meta-analysis very rigorously, several limitations should be acknowledged. First, in our metaanalysis, we included two cohort studies, seven cross-sectional studies, and four case-control studies. There was still lack of enough prospective cohort studies to evaluate the risk of NAFLD among hypothyroidism patients. Further prospective cohort studies are necessary to confirm our findings. Second, our research still had statistical heterogeneity, because there were inevitable differences in those included studies. For example, all the patients enrolled in those studies were from different countries. In the meta-regression analysis, we found

\section{REFERENCES}

1. Rinella ME. Nonalcoholic fatty liver disease: a systematic review. JAMA (2015) 313(22):2263-73. doi:10.1001/jama.2015.5370

2. Charlton MR, Burns JM, Pedersen RA, Watt KD, Heimbach JK, Dierkhising RA. Frequency and outcomes of liver transplantation for nonalcoholic steatohepatitis in the United States. Gastroenterology (2011) 141(4):1249-53. doi:10.1053/j.gastro.2011.06.061

3. Adams LA, Anstee QM, Tilg H, Targher G. Non-alcoholic fatty liver disease and its relationship with cardiovascular disease and other extrahepatic diseases. Gut (2017) 66(6):1138-53. doi:10.1136/gutjnl-2017-313884

4. Motamed N, Rabiee B, Poustchi H, Dehestani B, Hemasi GR, Khonsari $\mathrm{MR}$, et al. Non-alcoholic fatty liver disease (NAFLD) and 10-year risk of cardiovascular diseases. Clin Res Hepatol Gastroenterol (2017) 41(1):31-8. doi:10.1016/j.clinre.2016.07.005

5. Chang Y, Jung HS, Yun KE, Cho J, Cho YK, Ryu S. Cohort study of non-alcoholic fatty liver disease, NAFLD fibrosis score, and the risk of incident diabetes in a Korean population. Am J Gastroenterol (2013) 108(12):1861-8. doi:10.1038/ajg.2013.349

6. Mehran L, Amouzegar A, Rahimabad PK, Tohidi M, Tahmasebinejad Z, Azizi F. Thyroid function and metabolic syndrome: a population-based thyroid study. Horm Metab Res (2017) 49(3):192-200. doi:10.1055/s-0042-117279

7. Allelein S, Schott M. [Thyroid dysfunction]. MMW Fortschr Med (2016) 158(Spec No 1):45-52. doi:10.1007/s15006-016-7652-z that study design was a possible source of heterogeneity, but other sources were not identified. Third, most studies did not analyze the impact of thyroid hormone replacement therapy when exploring the risk of NAFLD among overt hypothyroidism or subclinical hypothyroidism patients. A recent study demonstrated that levothyroxine (LT4) had benefits on NAFLD in subclinical hypothyroid patients and LT4 supplementation played a beneficial role in delaying the development of NAFLD (23). More clinical trials are needed to evaluate the possible role of thyroid hormone replacement therapy in NAFLD among hypothyroidism patients.

In conclusion, our meta-analysis provides strong epidemiological evidence for the significant relationship between hypothyroidism and NAFLD. Both individuals with subclinical hypothyroidism and overt hypothyroidism are at a higher risk for the development of NAFLD than those with normal thyroid function. More prospective cohort studies are needed to further strengthen the relationship between NAFLD and hypothyroidism.

\section{AUTHOR CONTRIBUTIONS}

WH and J-aZ designed the study. WH, XA, LL, XS, QY, QL, and $\mathrm{J}$-aZ contributed to the literature search, interpretation, writing, and proofreading of the manuscript. WH, XA, LL, and QY extracted data and performed data analyses.

\section{FUNDING}

The present work was supported by grants from the National Natural Science Foundation of China (nos. 81670722 and 81471004).

8. Iglesias P, Bajo MA, Selgas R, Diez JJ. Thyroid dysfunction and kidney disease: an update. Rev Endocr Metab Disord (2017) 18(1):131-44. doi:10.1007/ s11154-016-9395-7

9. Rieben C, Segna D, da Costa BR, Collet TH, Chaker L, Aubert CE, et al. Subclinical thyroid dysfunction and the risk of cognitive decline: a meta-analysis of prospective cohort studies. J Clin Endocrinol Metab (2016) 101(12):4945-54. doi:10.1210/jc.2016-2129

10. Yang R, Yao L, Fang Y, Sun J, Guo T, Yang K, et al. The relationship between subclinical thyroid dysfunction and the risk of fracture or low bone mineral density: a systematic review and meta-analysis of cohort studies. J Bone Miner Metab (2017). doi:10.1007/s00774-017-0828-5

11. Eshraghian A, Hamidian Jahromi A. Non-alcoholic fatty liver disease and thyroid dysfunction: a systematic review. World J Gastroenterol (2014) 20(25):8102-9. doi:10.3748/wjg.v20.i25.8102

12. Chung GE, Kim D, Kim W, Yim JY, Park MJ, Kim YJ, et al. Non-alcoholic fatty liver disease across the spectrum of hypothyroidism. J Hepatol (2012) 57(1):150-6. doi:10.1016/j.jhep.2012.02.027

13. Pagadala MR, Zein CO, Dasarathy S, Yerian LM, Lopez R, McCullough AJ. Prevalence of hypothyroidism in nonalcoholic fatty liver disease. Dig Dis Sci (2012) 57(2):528-34. doi:10.1007/s10620-011-2006-2

14. Eshraghian A, Dabbaghmanesh MH, Eshraghian H, Fattahi MR, Omrani GR. Nonalcoholic fatty liver disease in a cluster of Iranian population: thyroid status and metabolic risk factors. Arch Iran Med (2013) 16(10):584-9. doi:0131610/AIM.007 
15. Mazo DF, Lima VM, Stefano JT, Rabelo F, Faintuch J, Oliveira CP. Glucolipidic indices in treated hypothyroidism associated with nonalcoholic fatty liver disease. Arq Gastroenterol (2011) 48(3):186-9. doi:10.1590/ S0004-28032011000300006

16. Moher D, Liberati A, Tetzlaff J, Altman DG. Preferred reporting items for systematic reviews and meta-analyses: the PRISMA statement. BMJ (2009) 339:b2535. doi:10.1136/bmj.b2535

17. Stang A. Critical evaluation of the Newcastle-Ottawa scale for the assessment of the quality of nonrandomized studies in meta-analyses. Eur J Epidemiol (2010) 25(9):603-5. doi:10.1007/s10654-010-9491-z

18. Cochran WG. The combination of estimates from different experiments. Biometrics (1954) 10(1):101-29. doi:10.2307/3001666

19. Higgins JP, Thompson SG, Deeks JJ, Altman DG. Measuring inconsistency in meta-analyses. BMJ (2003) 327(7414):557-60. doi:10.1136/bmj.327.7414.557

20. DerSimonian R, Laird N. Meta-analysis in clinical trials. Control Clin Trials (1986) 7(3):177-88. doi:10.1016/0197-2456(86)90046-2

21. Mantel N, Haenszel W. Statistical aspects of the analysis of data from retrospective studies of disease. J Natl Cancer Inst (1959) 22(4):719-48.

22. Egger M, Davey Smith G, Schneider M, Minder C. Bias in meta-analysis detected by a simple, graphical test. BMJ (1997) 315(7109):629-34. doi:10.1136/ bmj.315.7109.629

23. Liu L, Yu Y, Zhao M, Zheng D, Zhang X, Guan Q, et al. Benefits of levothyroxine replacement therapy on nonalcoholic fatty liver disease in subclinical hypothyroidism patients. Int J Endocrinol (2017) 2017:5753039. doi:10.1155/2017/5753039

24. Efstathiadou ZA, Kita MD, Polyzos SA. Thyroid dysfunction and nonalcoholic fatty liver disease. Minerva Endocrinol (2017). doi:10.23736/ S0391-1977.17.02617-7

25. Fabbrini E, Magkos F, Patterson BW, Mittendorfer B, Klein S. Subclinical hypothyroidism and hyperthyroidism have opposite effects on hepatic verylow-density lipoprotein-triglyceride kinetics. J Clin Endocrinol Metab (2012) 97(3):E414-8. doi:10.1210/jc.2011-2777

26. Nakade $Y$, Yoneda M. Relationship between non-alcoholic fatty liver disease and thyroid dysfunction. Intern Med (2016) 55(15):1941-2. doi:10.2169/ internalmedicine.55.7148

27. Geach T. Thyroid function: poor thyroid function linked to NAFLD. Nat Rev Endocrinol (2016) 12(8):434. doi:10.1038/nrendo.2016.103

28. Gokmen FY, Ahbab S, Ataoglu HE, Turker BC, Cetin F, Turker F, et al. FT3/ FT4 ratio predicts non-alcoholic fatty liver disease independent of metabolic parameters in patients with euthyroidism and hypothyroidism. Clinics (Sao Paulo) (2016) 71(4):221-5. doi:10.6061/clinics/2016(04)08

29. Demir S, Unubol M, Aypak SU, Ipek E, Aktas S, Ekren GS, et al. Histopathologic evaluation of nonalcoholic fatty liver disease in hypothyroidism-induced rats. Int J Endocrinol (2016) 2016:5083746. doi:10.1155/2016/5083746

30. Ludwig U, Holzner D, Denzer C, Greinert A, Haenle MM, Oeztuerk S, et al. Subclinical and clinical hypothyroidism and non-alcoholic fatty liver disease: a cross-sectional study of a random population sample aged 18 to 65 years. BMC Endocr Disord (2015) 15:41. doi:10.1186/s12902-015-0030-5

31. Ding WJ, Wang MM, Wang GS, Shen F, Qin JJ, Fan JG. Thyroid function is associated with non-alcoholic fatty liver disease in chronic hepatitis B-infected subjects. J Gastroenterol Hepatol (2015) 30(12):1753-8. doi:10.1111/jgh.12998

32. Tao Y, Gu H, Wu J, Sui J. Thyroid function is associated with non-alcoholic fatty liver disease in euthyroid subjects. Endocr Res (2015) 40(2):74-8. doi:10.3109/07435800.2014.952014

33. Bilgin H, Pirgon O. Thyroid function in obese children with non-alcoholic fatty liver disease. J Clin Res Pediatr Endocrinol (2014) 6(3):152-7. doi:10.4274/ Jcrpe. 1488

34. Misra S, Singh B. Insulin resistance and hypothyroidism: a complex relationship in non-alcoholic fatty liver disease. J Indian Med Assoc (2013) 111(5):324-6.

35. Sert A, Pirgon O, Aypar E, Yilmaz H, Odabas D. Subclinical hypothyroidism as a risk factor for the development of cardiovascular disease in obese adolescents with nonalcoholic fatty liver disease. Pediatr Cardiol (2013) 34(5):1166-74. doi:10.1007/s00246-013-0638-z

36. Mitchell F. Thyroid function: low T(4) levels a risk factor for fatty liver? Nat Rev Endocrinol (2012) 8(8):447. doi:10.1038/nrendo.2012.87

37. Zhang J, Sun H, Chen L, Zheng J, Hu X, Wang S, et al. Relationship between serum TSH level with obesity and NAFLD in euthyroid subjects. J Huazhong Univ Sci Technolog Med Sci (2012) 32(1):47-52. doi:10.1007/ s11596-012-0008-8
38. Xu C, Xu L, Yu C, Miao M, Li Y. Association between thyroid function and nonalcoholic fatty liver disease in euthyroid elderly Chinese. Clin Endocrinol (Oxf) (2011) 75(2):240-6. doi:10.1111/j.1365-2265.2011.04016.x

39. Gardner CJ, Richardson P, Wong C, Polavarapu N, Kemp GJ, Cuthbertson DJ. Hypothyroidism in a patient with non-alcoholic fatty liver disease. BMJ (2011) 342:c7199. doi:10.1136/bmj.c7199

40. Rodionova SV, Zvenigorodskaia LA, Tkachenko EV. [Thyroid dysfunction and soft fatty liver disease]. Eksp Klin Gastroenterol (2010) 7:92-6.

41. Silveira MG, Mendes FD, Diehl NN, Enders FT, Lindor KD. Thyroid dysfunction in primary biliary cirrhosis, primary sclerosing cholangitis and non-alcoholic fatty liver disease. Liver Int (2009) 29(7):1094-100. doi:10.1111/j.1478-3231.2009.02003.x

42. Kalaitzakis E. Fatigue in non-alcoholic fatty liver disease: is there a role for hypothyroidism. Gut (2009) 58(1):149-50.

43. Hanczycowa H, Lubczynska-Kowalska W. [Fatty liver degeneration in hypothyroidism]. Pol Tyg Lek (1977) 32(45):1765-6.

44. Lee KW, Bang KB, Rhee EJ, Kwon HJ, Lee MY, Cho YK. Impact of hypothyroidism on the development of non-alcoholic fatty liver disease: A 4-year retrospective cohort study. Clin Mol Hepatol (2015) 21(4):372-8. doi:10.3350/ cmh.2015.21.4.372

45. Pacifico L, Bonci E, Ferraro F, Andreoli G, Bascetta S, Chiesa C. Hepatic steatosis and thyroid function tests in overweight and obese children. Int J Endocrinol (2013) 2013:381014. doi:10.1155/2013/381014

46. Kaltenbach TE, Graeter T, Oeztuerk S, Holzner D, Kratzer W, Wabitsch M, et al. Thyroid dysfunction and hepatic steatosis in overweight children and adolescents. Pediatr Obes (2017) 12(1):67-74. doi:10.1111/ijpo.12110

47. Liangpunsakul S, Chalasani N. Is hypothyroidism a risk factor for non-alcoholic steatohepatitis? JClin Gastroenterol (2003) 37(4):340-3. doi:10.1097/00004836-200310000-00014

48. Parikh P, Phadke A, Sawant P. Prevalence of hypothyroidism in nonalcoholic fatty liver disease in patients attending a tertiary hospital in western India. Indian J Gastroenterol (2015) 34(2):169-73. doi:10.1007/ s12664-015-0541-z

49. Xu L, Ma H, Miao M, Li Y. Impact of subclinical hypothyroidism on the development of non-alcoholic fatty liver disease: a prospective case-control study. J Hepatol (2012) 57(5):1153-4. doi:10.1016/j.jhep.2012.05.025

50. Posadas-Romero C, Jorge-Galarza E, Posadas-Sanchez R, Acuna-Valerio J, Juarez-Rojas JG, Kimura-Hayama E, et al. Fatty liver largely explains associations of subclinical hypothyroidism with insulin resistance, metabolic syndrome, and subclinical coronary atherosclerosis. Eur J Endocrinol (2014) 171(3):319-25. doi:10.1530/EJE-14-0150

51. Ittermann T, Haring R, Wallaschofski H, Baumeister SE, Nauck M, Dorr M, et al. Inverse association between serum free thyroxine levels and hepatic steatosis: results from the Study of Health in Pomerania. Thyroid (2012) 22(6):568-74. doi:10.1089/thy.2011.0279

52. Bano A, Chaker L, Plompen EP, Hofman A, Dehghan A, Franco OH, et al. Thyroid function and the risk of nonalcoholic fatty liver disease: the Rotterdam Study. J Clin Endocrinol Metab (2016) 101(8):3204-11. doi:10.1210/ jc.2016-1300

53. Wang YF, Zhao JJ. The Relationship between the Broad Spectrum of Subclinical Hypothyroidism and NAFLD in Elderly Subjects (2014). Thesis for Master Degree, Shandong University.

54. Gluvic Z, Zaric B, Resanovic I, Obradovic M, Mitrovic A, Radak D, et al. Link between metabolic syndrome and insulin resistance. Curr Vasc Pharmacol (2017) 15(1):30-9. doi:10.2174/1570161114666161007164510

55. Casavalle PL, Lifshitz F, Romano LS, Pandolfo M, Caamano A, Boyer PM, et al. Prevalence of dyslipidemia and metabolic syndrome risk factor in overweight and obese children. Pediatr Endocrinol Rev (2014) 12(2):213-23.

56. Vyakaranam S, Vanaparthy S, Nori S, Palarapu S, Bhongir AV. Study of insulin resistance in subclinical hypothyroidism. Int J Health Sci Res (2014) 4(9):147-53.

57. Ryoo JH, Hong HP, Park SK, Ham WT, Chung JY. The risk for insulin resistance according to the degree of non-alcoholic fatty liver disease in Korean men. J Korean Med Sci (2016) 31(11):1761-7. doi:10.3346/jkms.2016.31.11.1761

58. Hulbert AJ. Thyroid hormones and their effects: a new perspective. Biol Rev Camb Philos Soc (2000) 75(4):519-631. doi:10.1111/j.1469-185X.2000. tb00054.x

59. Grover GJ, Mellstrom K, Ye L, Malm J, Li YL, Bladh LG, et al. Selective thyroid hormone receptor-beta activation: a strategy for reduction of weight, 
cholesterol, and lipoprotein (a) with reduced cardiovascular liability. Proc Natl Acad Sci U S A (2003) 100(17):10067-72. doi:10.1073/pnas.1633737100

60. Erion MD, Cable EE, Ito BR, Jiang H, Fujitaki JM, Finn PD, et al. Targeting thyroid hormone receptor-beta agonists to the liver reduces cholesterol and triglycerides and improves the therapeutic index. Proc Natl Acad Sci U S A (2007) 104(39):15490-5. doi:10.1073/pnas.0702759104

61. Gierach M, Junik R. The effect of hypothyroidism occurring in patients with metabolic syndrome. Endokrynol Pol (2015) 66(4):288-94. doi:10.5603/ EP.2015.0036

62. Tian L, Song Y, Xing M, Zhang W, Ning G, Li X, et al. A novel role for thyroid-stimulating hormone: up-regulation of hepatic 3-hydroxy-3-methylglutaryl-coenzyme A reductase expression through the cyclic adenosine monophosphate/protein kinase $\mathrm{A} / \mathrm{cyclic}$ adenosine monophosphate-responsive element binding protein pathway. Hepatology (2010) 52(4):1401-9. doi:10.1002/hep.23800

63. Song Y, Xu C, Shao S, Liu J, Xing W, Xu J, et al. Thyroid-stimulating hormone regulates hepatic bile acid homeostasis via SREBP-2/HNF-4alpha/CYP7A1 axis. J Hepatol (2015) 62(5):1171-9. doi:10.1016/j.jhep.2014.12.006

64. Li Y, Wang L, Zhou L, Song Y, Ma S, Yu C, et al. Thyroid stimulating hormone increases hepatic gluconeogenesis via CRTC2. Mol Cell Endocrinol (2017) 446:70-80. doi:10.1016/j.mce.2017.02.015

65. Zhang X, Song Y, Feng M, Zhou X, Lu Y, Gao L, et al. Thyroid-stimulating hormone decreases HMG-CoA reductase phosphorylation via AMP-activated protein kinase in the liver. JLipid Res (2015) 56(5):963-71. doi:10.1194/jlr. M047654

66. Koroglu E, Canbakan B, Atay K, Hatemi I, Tuncer M, Dobrucali A, et al. Role of oxidative stress and insulin resistance in disease severity of non-alcoholic fatty liver disease. Turk J Gastroenterol (2016) 27(4):361-6. doi:10.5152/ tjg.2016.16106

67. Coppola M, Glinni D, Moreno M, Cioffi F, Silvestri E, Goglia F. Thyroid hormone analogues and derivatives: actions in fatty liver. World J Hepatol (2014) 6(3):114-29. doi:10.4254/wjh.v6.i3.114
68. Grasselli E, Voci A, Canesi L, De Matteis R, Goglia F, Cioffi F, et al. Direct effects of iodothyronines on excess fat storage in rat hepatocytes. J Hepatol (2011) 54(6):1230-6. doi:10.1016/j.jhep.2010.09.027

69. Grasselli E, Voci A, Canesi L, Goglia F, Ravera S, Panfoli I, et al. Nonreceptor-mediated actions are responsible for the lipid-lowering effects of iodothyronines in FaO rat hepatoma cells. J Endocrinol (2011) 210(1):59-69. doi:10.1530/JOE-11-0074

70. Grasselli E, Voci A, Demori I, Canesi L, De Matteis R, Goglia F, et al 3,5-Diiodo-L-thyronine modulates the expression of genes of lipid metabolism in a rat model of fatty liver. J Endocrinol (2012) 212(2):149-58. doi:10.1530/ JOE-11-0288

71. Senese R, Cioffi F, de Lange P, Leanza C, Iannucci LF, Silvestri E, et al. Both 3,5-diiodo-L-thyronine and 3,5,3'-triiodo-L-thyronine prevent short-term hepatic lipid accumulation via distinct mechanisms in rats being fed a high-fat diet. Front Physiol (2017) 8:706. doi:10.3389/fphys.2017.00706

72. Zhang W, Tian LM, Han Y, Ma HY, Wang LC, Guo J, et al. Presence of thyrotropin receptor in hepatocytes: not a case of illegitimate transcription. J Cell Mol Med (2009) 13(11-12):4636-42. doi:10.1111/j.1582-4934.2008. 00670.x

Conflict of Interest Statement: The authors declare that the research was conducted in the absence of any commercial or financial relationships that could be construed as a potential conflict of interest.

The reviewer SP and handling Editor declared their shared affiliation.

Copyright $\odot 2017 \mathrm{He}, \mathrm{An}, \mathrm{Li}$, Shao, Li, Yao and Zhang. This is an open-access article distributed under the terms of the Creative Commons Attribution License (CC BY). The use, distribution or reproduction in other forums is permitted, provided the original author(s) or licensor are credited and that the original publication in this journal is cited, in accordance with accepted academic practice. No use, distribution or reproduction is permitted which does not comply with these terms. 